\title{
Arkadiusz Michał Współpraca w ramach działalności Kowalski innowacyjnej inicjatyw klastrowych w Polsce
}

\section{Cooperation in innovation activities within cluster initiatives in Poland}

This article focuses on clusters and the role they play in the innovation system in Poland. The first section examines theoretical background of the concept of clusters and cluster policy, which is emerging as an important element of governmental actions. Next, the author explores the role of clusters in innovativeness of the economy. From that perspective, cluster structures, understood as elements of innovation systems based on knowledge flows, create conditions that facilitate the development and transfer of technology, enabled by intense and constant co-operation between the creators and the beneficiaries of innovative solutions. Empirical part of the article examines the level of innovativeness of Polish clusters on the basis of data obtained from the surveys on innovation activity of industrial and service enterprises conducted by the Central Statistical Office.

\begin{tabular}{r|l}
\hline DOI & https://doi.org/10.31268/StudiaBAS.2020.06 \\
\hline Słowa kluczowe & $\begin{array}{l}\text { klastry, polityka klastrowa, inicjatywy klastrowe w Polsce, współpraca } \\
\text { w klastrach, działalność innowacyjna w Polsce }\end{array}$ \\
\hline Keywords & $\begin{array}{l}\text { clusters, cluster policy, cluster initiatives in Poland, cooperation in } \\
\text { clusters, innovation activities in Poland }\end{array}$ \\
\hline $\begin{array}{l}\text { Doktor hab. nauk ekonomicznych, profesor nadzwyczajny SGH } \\
\text { i kierownik Katedry Badań Gospodarek Państw Azji Wschodniej, } \\
\text { Kolegium Gospodarki Światowej, Szkoła Główna Handlowa } \\
\text { W Warszawie } ・ \text { @ arkadiusz.kowalski@sgh.waw.pl } \\
\text { ORCID 0000-0002-0857-352X }\end{array}$ \\
\hline
\end{tabular}

Artykuł jest rezultatem projektu badawczego nr 2016/21/B/HS4/03025 finansowanego przez Narodowe Centrum Nauki.

\section{Wstęp}

Przedmiotem artykułu jest koncepcja klastrów, która wpisuje się w nowoczesne modele innowacji i polityki innowacyjnej, akcentujące znaczenie interakcji i współpracy między różnymi rodzajami podmiotów tworzącymi narodowe i regionalne systemy innowacji. Znaczenie struktur klastrowych dla innowacyjności przedsiębiorstw wynika z ich oddziaływania na rozwój interakcji i współpracy między przedsiębiorstwami, a także między podmiotami gospodarczymi i naukowymi, w szczególności w kontekście transferu technologii z jednostek zajmujących się pracami badawczo-rozwojowymi do przedsiębiorstw przemysłowych. Celem artykułu jest przedstawienie stanu rozwoju klastrów w Polsce, ze szczególnym uwzględnieniem ich znaczenia dla innowacyjności gospodarki. Badanie bazuje m.in. na danych statystycznych pochodzących z realizowanych przez Główny Urząd Statystyczny badań działalności innowacyjnej przedsiębiorstw przemysłowych i usługowych. 
W pierwszej części opracowania dokonano klasyfikacji pojęciowej zjawiska klastrów, a także, z uwagi na fakt, że stają się one istotnym elementem polityki gospodarczej, opisano koncepcje polityki rozwoju opartej na klastrach. Następnie klastry są analizowane jako element systemu innowacji, w istotny sposób wpływający na zmianę dotychczasowego modelu współpracy między uczestnikami życia gospodarczego i naukowego i przyczyniający się do transferu technologii oraz dyfuzji innowacji. W kolejnej części skoncentrowano się na analizie danych statystycznych GUS dotyczących współpracy w działalności innowacyjnej polskich przedsiębiorstw, w tym w ramach inicjatyw klastrowych. Podsumowanie rozważań i wyników badań prowadzonych na wtórnych źródłach informacji zamyka artykuł.

\section{Klastry i inicjatywy klastrowe w kontekście polityki klastrowej}

Koncepcja klastrów stanowi przełom w tradycyjnym podejściu do zagadnień dotyczących innowacyjności i konkurencyjności gospodarki. Najbardziej znana definicja klastra stanowi, że jest to: geograficzne skupisko wzajemnie powiq̨zanych firm, wyspecjalizowanych dostawców, jednostek świadczq̨cych usługi, firm działajqcych w pokrewnych sektorach i zwiq̨zanych z nimi instytucji (na przykład uniwersytetów, jednostek normalizacyjnych i stowarzyszeń branżowych) w poszczególnych dziedzinach, konkurujqcych między sobq, ale również współpracujqcych ${ }^{1}$. Na podstawie tej definicji można wyróżnić trzy podstawowe cechy charakterystyczne klastrów²:

- koncentrację przestrzenną (geograficzną), która oznacza, że klastry rozwijają się w konkretnym regionie lub sąsiadujących regionach,

- koncentrację sektorową (specjalizacja), co oznacza, że klastry funkcjonują w ramach jednej lub kilku pokrewnych branż,

- powiązania i interakcje między uczestnikami klastra, przybierające formy koopetycji (coopetition), łączącej w sobie procesy konkurencji i kooperacji³.

W ostatnich dwóch dekadach zauważalny jest dynamiczny wzrost znaczenia i popularności klastrów, zarówno jako instrumentu polityki gospodarczej państwa, jak i modelu biznesowego wykorzystywanego do organizowania działalności gospodarczej, a także przedmiotu badań, w szczególności w naukach ekonomicznych i o zarządzaniu. W różnych państwach wspieranie

M.E. Porter, The competitive advantage of nations, Free Press, New York 1990.

2 A.M. Kowalski, A. Marcinkowski, Clusters versus cluster initiatives, with focus on ICT sector in Poland "European Planning Studies" 2014, Vol. 22, No. 1, s. 20-45, https://doi.org/10.1080/09654313.2012.731040.

3 Termin ten jest także tłumaczony jako „kooperencja”. Pojęcie to jest wielowymiarowe i wieloaspektowe, ponieważ może ona przybierać różne formy i występować na różnych poziomach w hierarchii systemów gospodarczych. Koopetycja oznacza strategię typu wygrywający-wygrywający w grze o sumie niezerowej. W tym ujęciu rywalizacja na rynku stanowi grę, która może przynosić korzyści wszystkim zaangażowanym podmiotom. Koopetycja może być także traktowana jako strategia wspólnego tworzenia wartości oraz rywalizacji przy podziale tej wartości w warunkach częściowej zbieżności celów i zmiennej strukturze gry o sumie dodatniej. W tym ujęciu współzależność przedsiębiorstw przynosi korzyści wszystkim stronom, jednak korzyści te nie zawsze są równe. 
klastrów staje się istotnym elementem polityki gospodarczej, a w dokumentach OECD 4 pojawiła się koncepcja polityki rozwoju opartej na klastrach (cluster-based economic development policy). W Unii Europejskiej szczególnie duże znaczenie ma wykorzystanie koncepcji klastrów jako instrumentu polityki innowacyjnej i tworzenia nowych źródeł wzrostu gospodarczego ${ }^{5}$. Rozwój klastrów może stanowić sposób na osiągnięcie inteligentnej specjalizacji (smart specialisation) regionów, które powinny koncentrować zasoby na kilku kluczowych obszarach i branżach, w których mają przewagę konkurencyjną. Dzięki temu inicjatywy klastrowe są uznawane za odpowiednie narzędzie strategii inteligentnych specjalizacji (Smart Specialisation Strategies, S3) ${ }^{6}$, stanowiącej istotny kierunek europejskiej polityki gospodarczej ${ }^{7}$.

Kształtowanie polityki klastrowej w Unii Europejskiej odbywa się na podstawie tzw. zarządzania wieloszczeblowego (multi-level governance, MLG), które oznacza, że każdy z poziomów administracji publicznej ma pewną autonomię działania, a zadania są podzielone między władze unijne, krajowe oraz kolejne szczeble samorządów. Podejście to ma szczególne znaczenie dla analizy polityki innowacyjnej ukierunkowanej terytorialnie ${ }^{8}$. W przypadku wspierania inicjatyw klastrowych możemy wyróżnić działania podejmowane na9:

- poziomie wspólnotowym, na którym jednym z najważniejszych rodzajów działań jest stymulowanie transgranicznej współpracy klastrów,

- poziomie krajowym (centralnym), obejmującym wspieranie silnych i relatywnie rozległych przestrzennie inicjatyw klastrowych, z koncentracją na projektach o charakterze „twardym”, inwestycyjnym,

- poziomie makroregionalnym, obejmującym zgrupowane w makroregiony województwa (np. makroregion Polskich Wschodniej),

- poziomie regionalnym, obejmującym klastry niewykraczające poza terytorium jednego województwa, znajdujące się zazwyczaj we wczesnej fazie rozwoju, z koncentracją na projektach o charakterze "miękkim”, które mają prowadzić do utworzenia oraz utrwalenia powiązania i ukształtowania ich struktury formalnoprawnej oraz modelu biznesowego ich funkcjonowania.

4 T.J.A. Roelandt, P. den Hertog, Cluster analysis and cluster-based policy making: the state of the art [w:] Cluster Analysis and Cluster-based Policy: New Perspectives and Rationale in Innovation Policy, eds. T.J.A. Roelandt, P. den Hertog. Organisation for Economic Cooperation and Development, Paris 1999.

5 A. Grycuk, Klastry a rozwój regionalny. Klaster usług biznesowych w Krakowie, „Studia BAS” 2017, nr 1(49), s. 133-167 [Rozwój regionalny, red. D. Grodzka, M. Korolewska].

6 M. Keller et al., Implementing S3 with Clusters - An Innovation Model for Transformative Activities, ,Journal for Research and Technology Policy Evaluation" 2019, Vol. 47, s. 23-34, https://doi.org/10.22163/fteval.2019.325

7 Wykorzystanie klastrów do realizacji strategii inteligentnych specjalizacji może pozwolić na: koncentrację zasobów w kilku priorytetowych branżach o kluczowym znaczeniu dla gospodarki regionalnej, w których regiony mają przewagę konkurencyjną, zapewnienie bardziej efektywnego wykorzystania środków publicznych przez osiągnięcie niezbędnej masy krytycznej inwestycji, zamiast rozpraszania środków na wiele różnych obszarów oraz wzmocnienie regionalnych systemów innowacji, skuteczności badań i rozwoju oraz przepływów wiedzy.

8 E. Magro, J.R. Wilson, Policy-mix evaluation: Governance challenges from new place-based innovation policies, „Research policy” 2019, Vol 48, No 10, https://doi.org/10.1016/j.respol.2018.06.010.

9 M.A. Weresa, A.M. Kowalski, E.B. Sieńko-Kułakowska, Rozwój klastrów i metody ewaluacji, Oficyna Wydawnicza SGH, Warszawa 2017. 
Pogląd o dużej efektywności polityki klastrowej wynika z założenia, że interwencja publiczna powinna mieć charakter wtórny do rynkowo zainicjowanych procesów rozwoju gospodarczego. W Europie struktura klastrów kształtuje się najczęściej zgodnie z podejściem oddolnym (bottom-up approach), według którego dominującą siłą są lokalne przedsiębiorstwa, w największym stopniu zintegrowane z gospodarką regionu. Zgodnie z koncepcją klastrów działania rządowe mają charakter pomocniczy i nie powinny zastępować mechanizmów rynkowych, a jedynie mogą je wspierać i korygować w tych aspektach, gdzie występują niedoskonałości rynku (market failures) i odpowiednie programy publiczne są w stanie efektywnie je korygować. Klastry rozwijane z kolei zgodnie z podejściem odgórnym (top-down approach), a więc z inicjatywy władz publicznych, mogą być mniej dynamiczne ${ }^{10}$.

Dla zrozumienia istoty polityki klastrowej konieczne jest zdefiniowanie przedmiotu jej oddziaływania. W tym celu niezbędne jest odróżnienie klastrów od tzw. inicjatyw klastrowych, które, aczkolwiek stanowią powiązane ze sobą kategorie, nie są pojęciami tożsamymi. Inicjatywy klastrowe można zdefiniować jako: zorganizowane działania mające na celu intensyfikację wzrostu i konkurencyjności klastrów w regionie, angażujq̨ce firmy klastrowe, rzq̨d oraz/lub środowisko badawcze ${ }^{11}$. Stanowią one więc mniej lub bardziej sformalizowaną i zinstytucjonalizowaną formę współpracy grupy lokalnych podmiotów, mającą na celu zainicjowanie funkcjonowania klastra lub rozwiązanie istotnych problemów już istniejącego. Kluczowym celem polityki klastrowej jest rozwój klastrów, rozumianych jako realne struktury gospodarcze składające się ze współpracujących i rywalizujących ze sobą w określonej bliskości geograficznej przedsiębiorstw funkcjonujących w danej branży i branżach powiązanych. Przedmiotem oddziaływania instrumentów publicznych muszą być jednak mniej lub bardziej zinstytucjonalizowane inicjatywy klastrowe, natomiast bezpośrednim beneficjentem wsparcia są organizacje klastrowe, które są podmiotami odpowiedzialnymi za wnioskowanie, realizację i rozliczanie konkretnych projektów. O ile klastry istnieją niezależnie od świadomości przedsiębiorstw oraz od jakiegokolwiek programu itd., to inicjatywa klastrowa polega na podjęciu określonego projektu lub rozwoju różnego rodzaju organizacji o charakterze klastra, co może stanowić obszar wsparcia w ramach polityki gospodarczej. Kluczowe znaczenie podejmowanych interwencji nie ogranicza się jednak do bezpośredniego beneficjenta, czyli organizacji klastrowej działającej na rzecz inicjatywy klastrowej, natomiast ich sensem jest jej rozwój i przekształcanie w realne klastry, a przez to zwiększanie konkurencyjności całej gospodarki regionalnej. Kluczową cechą polityki klastrowej jest więc oparcie podejmowanych w jej ramach działań na dynamice współpracy ${ }^{12}$. Ma to szczególne znaczenie w państwach takich jak Polska, w którym zawiązywane są często małe, embrionalne inicjatywy klastrowe, które nie spełniają najważniejszych założeń teoretycznego modelu klastra, tj. koncentracji geograficznej i branżowej (a więc nie pokrywają się one z spe-

10 Y.P. Collazzo, L. Kubelka, Shared value clusters in Austria , Competitiveness Review: An International Business Journal" 2019, Vol. 29, No 1, s. 61-76, https://doi.org/10.1108/cr-08-2016-0050.

11 Ö. Sölvell, G. Lindqvist, Ch. Ketels, The Cluster Initiative Greenbook, Ivory Tower AB, Stockholm 2003, s. 9.

12 J.R. Wilson, Cluster policy resilience: new challenges for a mature policy, "International Journal of Business Environment" 2019, Vol 10, No 4, s. 371-382, https://doi.org/10.1504/ijbe.2019.10023228. 
cjalizacją gospodarczą danego regionu), a także występowania silnych powiązań i współpracy między lokalnymi aktorami ${ }^{13}$.

Należy zwrócić uwagę, że w Polsce brak jest definicji prawnej klastra lub inicjatywy klastrowej oraz szczegółowego uregulowania aspektów związanych z ich funkcjonowaniem. Elastyczność tej koncepcji jest jednak w znacznym stopniu jej zaletą, ponieważ umożliwia przyjmowanie różnorodnych modeli biznesowych albo instrumentów wsparcia, w zależności od potrzeb i kontekstu podejmowanych działań. Funkcjonowanie klastrów odbywa się na podstawie regulacji prawnych obejmujących wiele różnych dziedzin prawa, w zależności od m.in. formy inicjatywy klastrowej, branży czy rodzaju podmiotów uczestniczących w klastrze. Mimo braku specjalnie dedykowanej formy prawnej organizacji inicjatywy klastrowej, tworzące ją podmioty mogą wybrać wiele form organizacyjnych przewidzianych przez Kodeks cywilny lub Kodeks spółek handlowych, np.: umowę o wzajemnej współpracy i wymianie doświadczeń, umowę stowarzyszenia lub możliwość stworzenia zaawansowanej organizacyjnie grupy kapitałowej. Wybór formy prawnej inicjatywy determinuje oczywiście zakres obowiązków uczestników, sposób jej funkcjonowania oraz zasady współpracy między członkami. Wiele inicjatyw klastrowych to także struktury nieformalne, oparte na wyrażeniu woli partnerskiej współpracy, np. w drodze listu intencyjnego.

W analizie klastrów w kontekście innowacyjności gospodarki istotne znaczenie mają klasyfikacje, w których podstawowym kryterium podziału klastrów jest znaczenie innowacji dla należących do nich podmiotów. Jedna z takich klasyfikacji została zaproponowana w dokumencie Komisji Europejskiej z 2002 r., gdzie wyróżniono:

- klastry tradycyjne, charakteryzujące dojrzałe branże, ze stałym stopniem zagęszczenia, oparte na długotrwałych relacjach, z lokalnym łańcuchem dostaw oraz absorbowaniem istniejących technologii,

- klastry oparte na wiedzy (science-based), tworzone przede wszystkim w stosunkowo młodych branżach o niestabilnym poziomie zagęszczenia i krótkotrwałych relacjach między podmiotami (m.in. joint venture na badania i rozwój), charakteryzujące się innowacjami technologicznymi ${ }^{14}$.

Klastry oparte na wiedzy, zwane inaczej badawczymi, różnią się od tradycyjnych układów klastrowych (lokalnych systemów produkcyjnych) tym, że kluczową rolę w sieci współpracy odgrywają podmioty związane bezpośrednio ze sferą badawczo-rozwojową (B+R). Podczas gdy klastry przemysłowe koncentrują się z reguły wokół przedsiębiorstw, to siłą napędową klastrów opartych na wiedzy są podmioty sektora B+R, np. uniwersytety. Członkowie klastrów badawczych, które są zawiązywane w nowoczesnych sektorach, np. biotechnologii, mikrotechnologii, nanotechnologii, optyki lub ekoenergii, w mniejszym stopniu zwracają uwagę na sprzedaż

13 A.M. Kowalski, Cluster Policy in Poland and its Role for the Competitiveness of Enterprises [w:] Poland: Competitiveness Report 2016. The role of economic policy and institutions, ed. M.A. Weresa, Warsaw School of Economics Press, Warsaw 2016, s. 225-239.

14 Regional Clusters in Europe, "Observatory of European SMEs" 2002, No. 3, European Commission, Brussels 2002. 
i marketing, a w większym na prace B+R i przygotowywanie innowacyjnych produktów, często z wykorzystaniem współpracy międzynarodowej ${ }^{15}$.

\section{Klastry jako element systemów innowacji}

Punktem wyjścia w analizie klastrów w kontekście innowacyjności gospodarki jest obserwacja występującej w gospodarce światowej geograficznej polaryzacji działalności innowacyjnej, w szczególności działalności badawczo-rozwojowej. Przykładowo, według badań C. Karlssona i M. Anderssona ${ }^{16}$ działalność $B+R$ jest z reguły bardziej skoncentrowana przestrzennie niż produkcja przemysłowa. Poszczególne branże lokują swoje centra $B+R$ nie w obszarach, w których ma miejsce produkcja, ale w miejscach lokalizacji działalności B+R innych branż. Jest to związane m.in. z uwarunkowanymi lokalnie procesami rozprzestrzeniania się wiedzy (knowledge spillovers), transferu technologii, przepływu informacji i rozwoju wykwalifikowanej siły roboczej. Klastry rozwijają się przede wszystkim w aglomeracjach miejskich, gdzie koncentruje się przedsiębiorczość innowacyjna, sprzyjająca tworzeniu m.in. startupów ${ }^{17}$. Jednocześnie wzrasta znaczenie otoczenia innowacyjnego, ponieważ zdolność innowacyjna staje się jednym z najważniejszych czynników lokalizacyjnych. Szczególne znaczenie odgrywa współpraca w klastrach kreatywnych, czyli klastrach funkcjonujących w sektorach kreatywnych i kultury ${ }^{18}$.

Klastry wpisują się w nowoczesny model procesów innowacyjnych, nazywany modelem systemowym lub interakcyjnym ${ }^{19}$. Według tej koncepcji najważniejszym źródłem innowacji nie jest sama wiedza, ale powiązania i współpraca między różnymi podmiotami posiadającymi poszczególne typy wiedzy, a także interaktywne uczenie się ${ }^{20}$. Podejście to wpisuje się w strategię „otwartej innowacji” (open innovation), zgodnie z którą przedsiębiorstwa powinny dążyć do wykorzystywania zewnętrznych źródeł innowacji, m.in. przez znajdowanie i łączenie pomysłów, które są komplementarne do prowadzonych przez nie prac B+R oraz przez współpracę z innymi jednostkami ${ }^{21}$. Istotne znaczenie dla realizacji strategii innowacji otwartej ma bliskość

15 M.A. Weresa, A.M. Kowalski, E.B. Sieńko-Kułakowska, Rozwój klastrów i metody ewaluacji, Oficyna Wydawnicza SGH, Warszawa 2017.

16 C. Karlsson, M. Andersson, The Location of Industry R\&D and the Location of University R\&D [w:] New Directions in Regional Economic Development, eds. Ch. Karlsson, A.E. Andersson, P.C. Cheshire, R.R. Stough, Advances in Spatial Science, Springer, Berlin 2009, s. 273-274.

17 A. Grycuk, Wybrane narzędzia wspierania startupów w Polsce , Studia BAS” 2019, nr 2(58), s. 153-181 [Uwarunkowania prowadzenia działalności gospodarczej w Polsce, red. A. Grycuk, P. Russel], https://doi.org/10.31268/ studiabas.2019.16.

18 S. Olko, Zarzqdzanie wiedza w klastrach i sieciach w przemysłach kreatywnych, CeDeWu, Warszawa 2017.

19 J.A. Johannessen, A systemic approach to innovation: the interactive innovation model, „Kybernetes” 2009, Vol. 38, No 1/2, s. 158-176.

20 B.A. Lundvall, National Systems of Innovation: Towards a Theory of Innovation and Interactive Learning, Pinter, London 1992, s. 9.

21 H.W. Chesbrough, M. Appleyard, Open Innovation and Strategy " "California Management Review" 2007, Vol. 50, No. 1, s. 57-76, https://doi.org/10.2307/41166416. 
geograficzna, która pomaga podmiotom gospodarczym, w szczególności małym i średnim przedsiębiorstwom, w zmniejszaniu kosztów transakcyjnych i ryzyka związanego ze współpracą w ramach działalności innowacyjnej ${ }^{22}$. Koncentracji wiedzy i kapitału sprzyjają klastry, w których działalność innowacyjna nie zależy już tylko od wewnętrznych zasobów jednostki, ale od umiejętnego łączenia wiedzy, umiejętności i działań różnych podmiotów funkcjonujących w danej gospodarce regionalnej. Powiązanie zlokalizowanych w tym samym regionie podmiotów siecią interakcji o formalnym i nieformalnym charakterze ułatwia wspólne podejmowanie prac $B+R$, wymianę wiedzy i informacji, transfer technologii oraz dyfuzję innowacji²3.

Rozwój klastrów wpłynął na ewolucję modelu współpracy między nauką i biznesem oraz między samymi przedsiębiorstwami. Formuła powiązań sieciowych nie tylko zbliżyła do siebie różne podmioty ze sfery gospodarki i nauki, ale umożliwiła ich funkcjonowanie jako niemalże jednego organizmu, prowadząc do efektów synergii. Dodatkową korzyścią dla przemysłu związaną ze współpracą technologiczną z uczelniami jest ich zdolność do podejścia interdyscyplinarnego, także w ramach jednego projektu ${ }^{24}$. Klastry stymulują współpracę przedsiębiorstw z podmiotami naukowymi w dwojaki sposób. Z jednej strony struktury klastrowe stwarzają możliwości udostępniania przedsiębiorcom wyników prac B+R, umożliwiając im komercjalizację odkryć naukowych. Z drugiej strony współpraca z zaangażowanymi w klastrach przedsiębiorstwami stymuluje naukowców do ukierunkowania podejmowanych przez nich prac badawczych zgodnie z potrzebami zgłaszanymi przez przemysł. Proces ten zwiększa stopień dopasowania podaży wyników prac badawczych do popytu na nie oraz pomaga w komercjalizacji wyników badań. Ważnym kanałem transferu technologii w ramach klastrów są nieformalne, bezpośrednie kontakty przedsiębiorców z podmiotami badawczymi i ekspertami. Dzięki temu wiedza powstała w klastrach przepływa szybciej w ich obrębie niż poza ich granicami, co w znacznej części dotyczy tzw. wiedzy ukrytej (tacit knowledge). Wiedza ukryta jest wiedzą osobistą, przejawiającą się w działaniach danej osoby, możliwą do przekazania tyko w sposób interakcyjny w wyniku bezpośrednich kontaktów między różnymi osobami, w szczególności znajdującymi się w bliskości geograficznej ${ }^{25}$. Ważne znaczenie w potencjale innowacyjnym klastrów odgrywają zasoby kapitału relacyjnego (relational capital), definiowanego jako: potencjał posiadany przez organizację w zwiq̨zku z jej relacjami zewnętrznymi, umożliwiającymi dostęp do wartości niematerialnych obejmujących wiedzę klientów, dostawców, rzq̨du lub stowarzyszeń branżowych ${ }^{26}$. Zasoby

22 C. Kapetaniou, S.H. Lee, Geographical proximity and open innovation of SMEs in Cyprus, "Small Business Economics" 2019, Vol 52, No 1, s. 261-276, https://doi.org/10.1007/s11187-018-0023-7.

23 A.M. Kowalski, Znaczenie klastrów dla innowacyjności gospodarki w Polsce, Oficyna Wydawnicza SGH, Warszawa 2013.

24 S. Scott, M. Hughes, S. Kraus, Developing relationships in innovation clusters, „Entrepreneurship \& Regional Development" 2019, Vol 31, No 1-2, s. 22-45, https://doi.org/10.1080/08985626.2018.1537145.

25 X. Ferras-Hernandez, P.A. Nylund, Clusters as Innovation Engines: The Accelerating Strengths of Proximity, „European Management Review" 2019, Vol. 16, No 1, s. 37-53, https://doi.org/10.1111/emre.12330.

26 N. Bontis, Managing organizational knowledge by diagnosing intellectual capital: framing and advancing the state of the field, "International Journal of Technology Management” 1999, Vol. 8, No. 5-8, s. 448-449, https://doi.org/10.1504/ijtm.1999.002780. 
kapitału relacyjnego w klastrach przekładają się na tworzenie stabilnych ram wielowymiarowej współpracy i są ważnym elementem rozwoju środowiska innowacyjnego ${ }^{27}$.

W literaturze ekonomicznej wskazuje się, że najwięcej interakcji i współpracy zachodzi między jednostkami wchodzącymi w skład systemów innowacyjnych na poziomie regionalnym ${ }^{28}$, a więc na poziomie przestrzennym odpowiadającym funkcjonowaniu klastrów. Istota regionu w procesach innowacyjnych znalazła potwierdzenie w teorii regionalnego systemu innowacji. Zgodnie z tą koncepcją, występowanie na danym obszarze układu podmiotów powiązanych siecią interakcji stymulujących przepływ wiedzy, określa potencjał danego regionu do tworzenia przełomowych innowacji i budowania konkurencyjnej gospodarki opartej na wiedzy ${ }^{29}$. Należy zwrócić jednocześnie uwagę, że regionalny system innowacyjny jest pojęciem znacznie szerszym niż klaster. Zbudowanie regionalnego systemu innowacyjnego wymaga sformalizowania istniejących w klastrze mechanizmów współpracy w zakresie przepływu wiedzy, transferu technologii i dyfuzji innowacji oraz wzmocnienia infrastruktury instytucjonalnej wspierającej procesy innowacyjne. Jednocześnie sprawne regionalne systemy innowacyjne determinują potencjał danego obszaru do tworzenia i rozwoju klastrów.

\section{Współpraca przedsiębiorstw w działalności innowacyjnej w ramach inicjatyw klastrowych w Polsce w świetle badań GUS}

Bazę, która umożliwia przeprowadzenie analizy innowacyjności klastrów w Polsce, tworzą dane statystyczne pochodzące z realizowanych przez GUS badań działalności innowacyjnej przedsiębiorstw przemysłowych i usługowych. Badania te przeprowadzono w ramach programu badań statystyki publicznej w tematach 1.43.02 - Innowacje w przemyśle (PNT-02) oraz 1.43.13 - Innowacje w sektorze usług (PNT-02/u). W artykule wykorzystano dane opublikowane w ostatniej dostępnej edycji publikacji GUS dotyczącej działalności innowacyjnej przedsiębiorstw, zawierającej przegląd wyników badania działalności innowacyjnej w sektorach przemysłowym oraz usługowym w latach $2015-2017^{30}$. W tabeli 1 przedstawiono udział przedsiębiorstw przemysłowych i usługowych prowadzących współpracę w działalności innowacyjnej w ramach inicjatywy klastrowej według sektorów i klas wielkości.

Z tabeli 1 wynika, że w latach 2015-2017 porozumienia o współpracy w ramach inicjatywy klastrowej dotyczące działalności innowacyjnej miało 5,7\% aktywnych innowacyjnie przedsiębiorstw przemysłowych oraz 5,4\% aktywnych innowacyjnie przedsiębiorstw usługowych. W ogólnej liczbie podmiotów współpracujących w zakresie działalności innowacyjnej, w ramach

27 H. Kantanen, Identity, image and stakeholder dialogue , "Corporate Communications: An International Journal” 2012, Vol. 17, No. 1, s. 56-72, https://doi.org/10.1108/13563281211196353.

28 K. Bosworth, P. Stoneman, U. Sinha, Technology Transfer, Information Flows and Collaboration: An Analysis of the CIS, EIMS Publication no. 36, European Commission, Luxembourg 1996.

29 B.T. Asheim, A. Isaksen, M. Trippl, Advanced Introduction to Regional Innovation Systems, Edward Elgar Publishing, 2019.

30 Główny Urząd Statystyczny, Urząd Statystyczny w Szczecinie, Działalność innowacyjna przedsiębiorstw w latach 2015-2017, Warszawa-Szczecin 2018. 
Tabela 1. Przedsiębiorstwa współpracujące w działalności innowacyjnej w ramach inicjatywy klastrowej według sektorów i klas wielkości w latach 2015-2017

\begin{tabular}{|c|c|c|c|}
\hline Wyszczególnienie & $\begin{array}{c}\text { Odsetek } \\
\text { przedsiębiorstw } \\
\text { ogółem }\end{array}$ & $\begin{array}{c}\text { Odsetek } \\
\text { przedsiębiorstw } \\
\text { aktywnych } \\
\text { innowacyjnie }\end{array}$ & $\begin{array}{c}\text { Odsetek } \\
\text { przedsiębiorstw, } \\
\text { które współpracowały } \\
\text { w zakresie } \\
\text { działalności } \\
\text { innowacyjnej }\end{array}$ \\
\hline \multicolumn{4}{|c|}{ Przedsiębiorstwa przemysłowe } \\
\hline Ogółem & 1,2 & 5,7 & 20,0 \\
\hline sektor publiczny & 2,9 & 10,0 & 30,5 \\
\hline sektor prywatny & 1,1 & 5,5 & 19,2 \\
\hline własność krajowa & 0,9 & 5,0 & 19,2 \\
\hline własność zagraniczna & 1,6 & 5,3 & 15,4 \\
\hline 10-49 pracujących & 0,4 & 3,0 & 15,3 \\
\hline 50-249 pracujących & 2,3 & 6,7 & 21,8 \\
\hline powyżej 249 pracujących & 6,9 & 11,0 & 22,4 \\
\hline \multicolumn{4}{|c|}{ Przedsiębiorstwa usługowe } \\
\hline Ogółem & 0,6 & 5,4 & 22,8 \\
\hline sektor publiczny & 3,9 & 11,5 & 28,8 \\
\hline sektor prywatny & 0,6 & 5,1 & 22,4 \\
\hline własność krajowa & 0,5 & 5,0 & 24,6 \\
\hline własność zagraniczna & 0,6 & 2,9 & 14,8 \\
\hline 10-49 pracujących & 0,4 & 4,6 & 24,5 \\
\hline 50-249 pracujących & 1,4 & 5,2 & 18,9 \\
\hline powyżej 249 pracujących & 4,7 & 10,4 & 27,4 \\
\hline
\end{tabular}

Źródło: na podstawie baz danych zamieszczonych na stronach GUS; Główny Urząd Statystyczny, Urząd Statystyczny w Szczecinie, Działalność innowacyjna przedsiębiorstw w latach 2015-2017, Warszawa, Szczecin 2018.

klastrów współpracowało 20\% przedsiębiorstw przemysłowych i 22,8\% usługowych. Wśród podmiotów prowadzących współpracę w zakresie działalności innowacyjnej, które funkcjonowały w ramach klastrów, najwyższy odsetek zarówno w sektorze przemysłowym, jak i usługowym stanowiły przedsiębiorstwa duże, zatrudniające 250 i więcej osób.

Duże znaczenie klastrów dla procesów innowacyjnych sprawia, że obszar ich funkcjonowania utożsamia się często przede wszystkim z sektorami wysokich technologii. Inicjatywy klastrowe są jednak tworzone w sektorach przemysłowych i usługowych o różnej intensywności działalności B+R, co przedstawiono w tabeli 2.

Biorąc pod uwagę poziom techniki spośród przedsiębiorstw przemysłowych największy odsetek podmiotów współpracujących w ramach inicjatywy klastrowej stanowiły przedsiębiorstwa zaliczane do wysokiej techniki (23,4\%), natomiast najmniejszy - do niskiej techniki (14,3\%). Podobnie, na tle całego sektora usługowego, większą skłonność do współpracy w ramach klastrów 
Tabela 2. Przedsiębiorstwa prowadzące współpracę w działalności innowacyjnej w ramach inicjatywy klastrowej według poziomu techniki (sektor przemysłowy), zaangażowania wiedzy (usługi) oraz w sektorze ICT w latach 2015-2017

\begin{tabular}{|c|c|c|c|}
\hline & $\begin{array}{c}\text { Odsetek } \\
\text { przedsiębiorstw } \\
\text { ogółem }\end{array}$ & $\begin{array}{c}\text { Odsetek } \\
\text { przedsiębiorstw } \\
\text { aktywnych } \\
\text { innowacyjnie }\end{array}$ & $\begin{array}{c}\text { Odsetek } \\
\text { przedsiębiorstw, } \\
\text { które współpracowały } \\
\text { w zakresie } \\
\text { działalności } \\
\text { innowacyjnej }\end{array}$ \\
\hline Ogółem przemysł i usługi & 0,9 & 5,6 & 20,8 \\
\hline Ogółem przemysł & 1,2 & 5,7 & 20,0 \\
\hline $\begin{array}{l}\text { Przetwórstwo przemysłowe, } \\
\text { w tym: }\end{array}$ & 1,1 & 5,6 & 19,5 \\
\hline wysoka technika & 5,5 & 10,0 & 23,4 \\
\hline średniowysoka technika & 3,0 & 8,7 & 20,7 \\
\hline średnioniska technika & 1,2 & 5,8 & 20,2 \\
\hline niska technika & 0,4 & 2,5 & 14,3 \\
\hline Ogółem usługi, w tym: & 0,6 & 5,4 & 22,8 \\
\hline usługi wysokiej techniki & 2,8 & 9,7 & 26,3 \\
\hline $\begin{array}{l}\text { usługi finansowe oparte } \\
\text { na wiedzy }\end{array}$ & 1,5 & 7,0 & 24,0 \\
\hline Sektor ICT łącznie & 1,9 & 6,5 & 21,6 \\
\hline $\begin{array}{l}\text { Sektor ICT w przemyśle - } \\
\text { ogółem }\end{array}$ & 2,8 & 5,1 & 12,5 \\
\hline $\begin{array}{l}\text { Sektor ICT w usługach - } \\
\text { ogółem }\end{array}$ & 1,7 & 6,9 & 25,1 \\
\hline
\end{tabular}

Źródło: jak pod tabelą 1.

wykazywały podmioty oferujące usługi wysokiej techniki oraz usługi finansowe oparte na wiedzy. Należy jednak podkreślić, że klastry w Polsce powstają także w sektorach niskiej techniki. To, że klastry te funkcjonują w tradycyjnych sektorach, nie oznacza jednak, że należące do nich podmioty nie wykorzystują nowoczesnych technologii i nie następuje między nimi dynamiczny przepływ wiedzy. Przeciwnie, dzięki współpracy z uczestniczącymi w klastrach podmiotami naukowymi oraz innymi przedsiębiorstwami, również dla przedsiębiorstw działających w sektorach niskiej techniki otwierają się nowe możliwości rozwoju i szansa na włączanie w procesy produkcyjne innowacyjnych rozwiązań. Ma to szczególnie istotne znaczenie dla Polski, która w znacznym stopniu ma przewagi komparatywne w branżach tradycyjnych, niezaliczanych do sektorów wysokiej techniki.

Badania nad wpływem klastrów na innowacyjność mają istotne znaczenie w kontekście identyfikacji priorytetów polityki gospodarczej. Odgrywa to ogromną rolę w kontekście obserwowanego w Unii Europejskiej rosnącego znaczenia polityki gospodarczej ukierunkowanej na wspieranie najbardziej konkurencyjnych ośrodków gospodarczych. U podstaw takiej koncepcji polityki leży przekonanie, że koncentracja instrumentów wsparcia na podmiotach, które są 
Tabela 3. Przedsiębiorstwa przemysłowe prowadzące współpracę w działalności innowacyjnej w ramach inicjatywy klastrowej wg regionów w latach 2015-2017

\begin{tabular}{|c|c|c|c|}
\hline Regiony & $\begin{array}{l}\text { Odsetek } \\
\text { przedsiębiorstw } \\
\text { ogółem }\end{array}$ & $\begin{array}{c}\text { Odsetek } \\
\text { przedsiębiorstw } \\
\text { aktywnych } \\
\text { innowacyjnie }\end{array}$ & $\begin{array}{c}\text { Odsetek } \\
\text { przedsiębiorstw, } \\
\text { które } \\
\text { współpracowały } \\
\text { w zakresie } \\
\text { działalności } \\
\text { innowacyjnej }\end{array}$ \\
\hline lubelski & 2,2 & 9,5 & 35,9 \\
\hline podkarpacki & 2,2 & 10,5 & 37,1 \\
\hline podlaski & 1,9 & 10,0 & 39,4 \\
\hline małopolski & 1,8 & 7,5 & 21,7 \\
\hline kujawsko-pomorski & 1,2 & 6,7 & 24,0 \\
\hline mazowiecki & 1,2 & 5,7 & 16,1 \\
\hline warszawski stołeczny & 1,7 & 6,9 & 17,8 \\
\hline mazowiecki regionalny & 0,5 & 3,4 & 12,0 \\
\hline śląski & 1,2 & 5,8 & 20,0 \\
\hline świętokrzyski & 1,1 & 5,1 & 16,7 \\
\hline łódzki & 1,0 & 5,7 & 25,0 \\
\hline zachodniopomorski & 1,0 & 4,9 & 21,2 \\
\hline pomorski & 0,9 & 4,5 & 18,4 \\
\hline wielkopolski & 0,9 & 4,6 & 16,0 \\
\hline dolnośląski & 0,8 & 4,0 & 14,4 \\
\hline opolski & 0,5 & 2,3 & 7,9 \\
\hline warmińsko-mazurski & 0,5 & 3,2 & 13,6 \\
\hline lubuski & 0,3 & 1,8 & 7,3 \\
\hline Polska & 1,2 & 5,7 & 20,0 \\
\hline
\end{tabular}

Źródło: jak pod tabelą 1.

w stanie konkurować w warunkach gospodarki globalnej i odnieść sukces w dłuższej perspektywie czasowej, przyczyni się do racjonalizacji i większej efektywności wydatków publicznych. W związku z powyższym dokonuje się ewolucja założeń polityki strukturalnej Unii Europejskiej i przeniesienie punktu ciężkości z wyrównywania różnic rozwojowych między słabiej i lepiej rozwiniętymi państwami członkowskimi na rzecz wspierania lokalizacji o największym potencjale rozwojowym, także w regionach słabiej rozwiniętych. Takie podejście sprzyja z jednej strony wspieraniu biegunów wzrostu w gospodarce, a z drugiej tworzeniu warunków do rozprzestrzeniania się impulsów rozwojowych na całą gospodarkę. W tabeli 3 i 4 przedstawiono udział przedsiębiorstw przemysłowych i usługowych prowadzących współpracę w działalności innowacyjnej w ramach inicjatywy klastrowej według regionów w Polsce.

Uwzględniając przekrój terytorialny, największy odsetek aktywnych innowacyjnie przedsiębiorstw przemysłowych współpracujących w ramach inicjatywy klastrowej wystąpił w wojewódz- 
Tabela 4. Przedsiębiorstwa usługowe prowadzące współpracę w działalności innowacyjnej w ramach inicjatywy klastrowej według regionów

\begin{tabular}{|c|c|c|c|}
\hline Regiony & $\begin{array}{c}\text { Odsetek } \\
\text { przedsiębiorstw } \\
\text { ogółem }\end{array}$ & $\begin{array}{c}\text { Odsetek } \\
\text { przedsiębiorstw } \\
\text { aktywnych } \\
\text { innowacyjnie }\end{array}$ & $\begin{array}{c}\text { Odsetek } \\
\text { przedsiębiorstw, } \\
\text { które } \\
\text { współpracowały } \\
\text { w zakresie } \\
\text { działalności } \\
\text { innowacyjnej }\end{array}$ \\
\hline podkarpacki & 2,4 & 18,3 & 73,7 \\
\hline świętokrzyski & 1,3 & 24,0 & 75,0 \\
\hline śląski & 0,9 & 8,2 & 28,2 \\
\hline lubuski & 0,8 & 6,6 & 53,8 \\
\hline mazowiecki & 0,8 & 4,8 & 17,9 \\
\hline warszawski stołeczny & 1,1 & 5,1 & 17,7 \\
\hline mazowiecki regionalny & 0,1 & 1,8 & 28,6 \\
\hline dolnośląski & 0,7 & 5,3 & 32,6 \\
\hline kujawsko-pomorski & 0,5 & 7,8 & 42,9 \\
\hline łódzki & 0,5 & 4,7 & 15,6 \\
\hline pomorski & 0,4 & 2,4 & 8,4 \\
\hline warmińsko-mazurski & 0,4 & 9,1 & 33,3 \\
\hline wielkopolski & 0,4 & 4,1 & 23,7 \\
\hline zachodniopomorski & 0,3 & 3,1 & 100,0 \\
\hline lubelski & 0,2 & 2,4 & 40,0 \\
\hline małopolski & 0,2 & 2,0 & 7,2 \\
\hline opolski & - & - & - \\
\hline podlaski & - & - & - \\
\hline Polska & 0,6 & 5,4 & 22,8 \\
\hline
\end{tabular}

Źródło: jak pod tabelą 1.

twie podkarpackim (10,5\%), podlaskim (10\%) i lubelskim (9,5\%), natomiast przedsiębiorstw usługowych w województwie świętokrzyskim (24\%), podkarpackim (18,3\%) i warmińsko-mazurskim $(9,1 \%)$. Warto podkreślić, że wymienione województwa charakteryzują się niskim poziomem życia, niskim poziomem rozwoju gospodarczego oraz słabo rozwiniętą i niewystarczającą infrastrukturą transportową. W związku z tym w ostatnich latach otrzymały one dodatkowe wsparcie z funduszy strukturalnych UE, głównie z programu operacyjnego „Rozwój Polski Wschodniej na lata 2007-2013" oraz programu operacyjnego „Polska Wschodnia 2014-2020”. Wśród priorytetów tych programów znalazło się wspieranie tworzenia sieci i współpracy, także inicjatyw klastrowych. W ten sposób dostępność unijnego wsparcia publicznego przyczyniła się do wysokiego poziomu współpracy i „klastrowania” innowacyjnych przedsiębiorstw w Polsce Wschodniej, mimo ogólnie niskiego poziomu rozwoju i innowacyjności w tym makroregionie. Przykładem 
jest sztandarowy przykład polskiego klastra - Dolina Lotnicza, której większość podmiotów jest zlokalizowanych w województwie podkarpackim. Pokazuje to, że nawet w regionach o niskim poziomie rozwoju mogą zaistnieć atrakcyjne lokalizacje dla rozwoju klastrów. Miejsca te mogą pełnić funkcję „biegunów wzrostu”, stanowiących źródło impulsów rozwojowych rozprzestrzeniających się na otaczające je obszary.

Badania dotyczące klastrów w Polsce i ich wpływu na innowacje są także przeprowadzane cyklicznie przez Polską Agencję Rozwoju Przedsiębiorczości. Zgodnie z ostatnią edycją raportu Benchmarking klastrów w Polsce $e^{31}$ projekty BRI (badawczo-rozwojowe i innowacyjne) realizowało 23 z 40 (57,5\%) badanych inicjatyw klastrowych, przy czym brało w nich udział przeciętnie 12\% podmiotów członkowskich. Transfer wiedzy był realizowany w 21 (55\%) badanych inicjatywach klastrowych. Jedynie w 6 (15\%) klastrów dokonano zgłoszeń patentowych, natomiast wsparcie w uzyskiwaniu ochrony własności intelektualnej oferowało 14 (35\%) badanych klastrów. Powyższe dane potwierdzają, że inicjatywy klastrowe w pewnym stopniu przyczyniają się do zwiększania innowacyjności polskiej gospodarki, aczkolwiek potencjał związany z rozwojem klastrów jako elementów narodowego i regionalnych systemów innowacji w znacznym stopniu nie został jeszcze wykorzystany. Największą zdolnością innowacyjną i najwyższym poziomem transferu technologii charakteryzują się obecnie krajowe klastry kluczowe (KKK), a więc wyłonione w procedurze konkursowej inicjatywy klastrowe o istotnym znaczeniu dla gospodarki państwa i wysokiej konkurencyjności międzynarodowej.

\section{Podsumowanie}

W nowoczesnym podejściu do tworzenia innowacji najważniejszą rolę odgrywają interakcje i współpraca między poszczególnymi podmiotami życia naukowego i gospodarczego. Środowiskiem w szczególny sposób sprzyjającym kooperacji przedsiębiorstw są klastry, które stanowią jeden z najlepszych sposobów stymulowania współpracy horyzontalnej w gospodarce. Koncepcja klastrów odpowiada na występujące we współczesnej gospodarce zjawisko rozproszenia wiedzy i kapitału sprawiające, że efektywna działalność innowacyjna nie zależy już tylko od wewnętrznych zasobów organizacji, ale przede wszystkim od odpowiedniego połączenia wiedzy i umiejętności różnych podmiotów, instytucji, branż i dziedzin nauki. Związki i kontakty między poszczególnymi podmiotami stanowią system, w którym przedsiębiorstwa o ograniczonym dostępie do wiedzy zdobywają ją z zewnątrz, co sprzyja powstawaniu nowych pomysłów i pobudzaniu innowacyjności. Struktury klastrowe zajmują coraz ważniejsze miejsce w narodowym oraz regionalnych i branżowych systemach innowacji, ponieważ w elastyczny sposób zbliżają do siebie poszczególne podmioty oraz ułatwiają im wchodzenie w bezpośrednie interakcje.

Jedną z podstawowych słabości narodowego systemu innowacji w Polsce jest niski stopień współpracy między poszczególnymi podmiotami wchodzącymi w skład tego systemu, przede wszystkim między przedsiębiorstwami oraz między biznesem i nauką. Sposobem na pokonywanie tego niekorzystnego zjawiska jest rozwój klastrów, które stanowią elastyczną formę

31 PARP, Benchmarking klastrów w Polsce - edycja 2018, Warszawa 2018. 
organizacji działalności gospodarczej, umożliwiającą angażowanie różnego typu podmiotów w poszczególne etapy procesu innowacyjnego. Należy jednak pamiętać, że wiele klastrów w Polsce znajduje się na początkowym etapie rozwoju i potencjał z nimi związany w znacznym stopniu nie został jeszcze wykorzystany. Przeprowadzona w artykule analiza danych GUS wskazuje, że w latach 2015-2017 w ramach klastrów współpracowało 1,2\% przedsiębiorstw przemysłowych i 0,6\% przedsiębiorstw z sektora usług, a odsetek podmiotów zaangażowanych w klastry wzrastał wraz ze wzrostem wielkości przedsiębiorstw. Oznacza to, że istnieje szczególne wyzwanie związane z angażowaniem w klastry małych i średnich przedsiębiorstw, które tradycyjnie niechętnie inwestują w innowacyjne rozwiązania, m.in. z powodu braku kapitału oraz z obawy przed nierentownością takich decyzjij ${ }^{32}$. Jednocześnie skłonność do „klastrowania” była największa wśród przedsiębiorstw przemysłowych funkcjonujących w branżach zaliczanych do wysokiej techniki (5,5\% ogółu badanych przedsiębiorstw), a najmniejsza - do niskiej techniki $(0,4 \%)$, natomiast w sektorze usług - wśród przedsiębiorstw oferujących usługi wysokiej techniki (2,8\% w porównaniu z $0,6 \%$ udziału przedsiębiorstw zaangażowanych w klastry w całym sektorze usług) oraz usługi finansowe oparte na wiedzy (1,5\%). W tym kontekście istotna jest obserwacja, że klastry powstają również w branżach mniej zaawansowanych technologiczne, co również ma ważne znaczenie dla innowacyjności polskiej gospodarki, która w znacznym stopniu charakteryzuje się przewagami komparatywnymi w tradycyjnych rodzajach działalności gospodarczej. W przekroju terytorialnym największy odsetek przedsiębiorstw przemysłowych współpracujących w ramach inicjatyw klastrowych wystąpił w województwie podkarpackim i lubelskim (2,2\%) oraz podlaskim (1,9\%) natomiast przedsiębiorstw usługowych w województwie podkarpackim $(2,4 \%)$ i świętokrzyskim (1,3\%). Dane te, wraz z obserwacjami o wyłanianiu się silnych klastrów w regionie Polski Wschodniej, np. Doliny Lotniczej w województwie podkarpackim, świadczą o tym, że nawet w słabiej rozwiniętych regionach mogą wykształcać się bieguny wzrostu, będące źródłem impulsów rozwojowych dla gospodarki, a klastry mogą stanowić efektywny instrument zarówno polityki innowacyjnej, jak i regionalnej. Rozwój klastrów ma istotne znaczenie w kontekście identyfikacji priorytetów polityki gospodarczej, która powinna być w większym stopniu ukierunkowana na innowacje oraz wspieranie współpracy między przedsiębiorstwami i sektorem przemysłowym i naukowym.

\section{Bibliografia}

Asheim B.T., Isaksen A., Trippl M., Advanced Introduction to Regional Innovation Systems, Edward Elgar Publishing, 2019.

Bontis N., Managing organizational knowledge by diagnosing intellectual capital: framing and advancing the state of the field, "International Journal of Technology Management” 1999, Vol. 8, No. 5-8, https://doi.org/10.1504/ ijtm.1999.002780.

32 J. Grzywacz, E. Jagodzińska-Komar, Innowacyjność polskich przedsiębiorstw na tle Unii Europejskiej, „Roczniki Ekonomii i Zarządzania" 2018, t. 10, nr 3, s. 25-36, https://doi.org/10.18290/reiz.2018.10.3-2. 
Bosworth K., Stoneman P., Sinha U., Technology Transfer, Information Flows and Collaboration: An Analysis of the CIS, EIMS Publication no. 36, European Commission, Luxembourg 1996.

Chesbrough H.W., Appleyard M., Open Innovation and Strategy, "California Management Review” 2007, Vol. 50, No. 1, https://doi.org/10.2307/41166416.

Collazzo Y.P., Kubelka L., Shared value clusters in Austria, "Competitiveness Review: An International Business Journal" 2019, Vol. 29, No 1, https://doi.org/10.1108/cr-08-2016-0050.

Ferras-Hernandez X., Nylund P.A., Clusters as Innovation Engines: The Accelerating Strengths of Proximity, „European Management Review" 2019, Vol. 16, No 1, https://doi.org/10.1111/emre.12330.

Główny Urząd Statystyczny, Urząd Statystyczny w Szczecinie, Działalność innowacyjna przedsiębiorstw w latach 2015-2017, Warszawa, Szczecin 2018.

Grycuk A., Klastry a rozwój regionalny. Klaster usług biznesowych w Krakowie, "Studia BAS” 2017, nr 1(49) [Rozwój regionalny, red. D. Grodzka, M. Korolewska].

Grycuk A., Wybrane narzędzia wspierania startupów w Polsce, „Studia BAS” 2019, nr 2(58) [Uwarunkowania prowadzenia działalności gospodarczej w Polsce, red. A. Grycuk, P. Russel], https://doi.org/10.31268/studiabas.2019.16.

Grzywacz, J., Jagodzińska-Komar, E., Innowacyjność polskich przedsiębiorstw na tle Unii Europejskiej, „Roczniki Ekonomii i Zarządzania" 2018, t. 10, nr 3, https://doi.org/10.18290/reiz.2018.10.3-2.

Johannessen J.A., A systemic approach to innovation: the interactive innovation model, "Kybernetes" 2009, Vol. 38, No. 1/2, https://doi.org/10.1108/03684920910930330.

Kantanen H., Identity, image and stakeholder dialogue, "Corporate Communications: An International Journal” 2012, Vol. 17, Iss. 1, https://doi.org/10.1108/13563281211196353.

Kapetaniou C., Lee S.H., Geographical proximity and open innovation of SMEs in Cyprus, „Small Business Economics" 2019, Vol. 52, No. 1, https://doi.org/10.1007/s11187-018-0023-7.

Karlsson C., Andersson M., The Location of Industry R\&D and the Location of University R\&D [w:] New Directions in Regional Economic Development, eds. Ch. Karlsson, A.E. Andersson, P.C. Cheshire, R.R. Stough, Advances in Spatial Science, Springer, Berlin 2009.

Keller M. et al., Implementing S3 with Clusters - An Innovation Model for Transformative Activities, "Journal for Research and Technology Policy Evaluation" 2019, Vol. 47, https://doi.org/10.22163/fteval.2019.325.

Kowalski A.M., Cluster Policy in Poland and its Role for the Competitiveness of Enterprises [w:] Poland: Competitiveness Report 2016. The role of economic policy and institutions, ed. M.A. Weresa, Warsaw School of Economics Press, Warsaw 2016.

Kowalski A.M., Marcinkowski A., Clusters versus cluster initiatives, with focus on ICT sector in Poland, "European Planning Studies" 2014, Vol. 22, No. 1, https://doi.org/10.1080/09654313.2012.731040.

Kowalski A.M., Znaczenie klastrów dla innowacyjności gospodarki w Polsce, Oficyna Wydawnicza SGH, Warszawa 2013.

Lundvall B.A., National Systems of Innovation: Towards a Theory of Innovation and Interactive Learning, Pinter, London 1992.

Magro E., Wilson J.R., Policy-mix evaluation: Governance challenges from new place-based innovation policies, „Research policy” 2019, Vol. 48, No. 10, https://doi.org/10.1016/j.respol.2018.06.010.

Olko S., Zarządzanie wiedza w klastrach i sieciach w przemysłach kreatywnych, CeDeWu, Warszawa 2017.

PARP, Benchmarking klastrów w Polsce - edycja 2018, Warszawa 2018. 
Porter M.E., The competitive advantage of nations, Free Press, New York 1990.

Regional Clusters in Europe, "Observatory of European SMEs” 2002, No. 3, European Commission, Brussels 2002.

Roelandt T.J.A., den Hertog P., Cluster analysis and cluster-based policy making: the state of the art [w:] Cluster Analysis and Cluster-based Policy: New Perspectives and Rationale in Innovation Policy, eds. T.J.A. Roelandt, P. den Hertog, Organisation for Economic Cooperation and Development, Paris 1999.

Scott S., Hughes M., Kraus S., Developing relationships in innovation clusters, „Entrepreneurship \& Regional Development" 2019, Vol. 31, No 1-2, https://doi.org/10.1080/08985626.2018.1537145.

Sölvell Ö., Lindqvist G., Ketels Ch., The Cluster Initiative Greenbook, Ivory Tower AB, Stockholm 2003.

Weresa M.A., Kowalski A.M., Sieńko-Kułakowska E.B., Rozwój klastrów i metody ewaluacji, Oficyna Wydawnicza SGH, Warszawa 2017.

Wilson J.R., Cluster policy resilience: new challenges for a mature policy, „International Journal of Business Environment" 2019, Vol. 10, No 4, https://doi.org/10.1504/ijbe.2019.10023228. 